\title{
Competitive strategies adopted by small and medium dairy processors in Nairobi County, Kenya
}

\author{
Veronica Mwangangi, David Kabata (PhD), Jeketule Jacob Soko (PhD) \\ Tangaza University College, Kenya
}

\begin{abstract}
The dairy industry in Kenya plays an important role in the creation of employment and food security. It is one of the major drivers which the country is using to achieve the Sustainable Development goals and Kenya Vision 2030. The success of the sector however, is dependent on the ability of the different firms to improve performance through gaining a competitive edge that is sustainable. The main purpose of this study was to find out the competitive strategies used by small and medium dairy processors in Nairobi County. The study used a descriptive survey research design, and a census of the firms. Questionnaire was the key instrument of data collection. The data collected was analyzed using descriptive statistics. The summarized information was presented using tables and charts. The study found out that the dairy enterprises had adopted the differentiation strategy more than the cost leadership, cost focus and differentiation focus strategies as represented by $32 \%$ of the respondents. It is recommended that a longitudinal and inferential study be carried out on a larger study population of the small and medium dairy firms, which extends beyond Nairobi County. The study recommended that a replication of the study be carried out using more objective measures of performance like profits. The conclusions made from the study findings may be used by managers of both existing firms and new entrants into the industry, who may need to make decisions on what competitive strategies may be suited to their business in order to position themselves in the industry and to improve performance.
\end{abstract}

Key Words: Competitive Strategies, Competitive advantage, Cost Leadership, Differentiation, Cost Focus, Differentiation Focus

\section{INTRODUCTION}

$\mathrm{P}$ resent day globalization has led to heightened competition among business firms (Kinyanjui et al., 2016), and created a business environment that is turbulent and highly competitive (Schwab, 2019). Consequently, firms are forced to find unique ways of creating and sustaining competitiveness for their survival (Laban and Deya, 2019). According to Omari et al., 2016), the desired competitiveness can be achieved by developing competitive strategies. To remain profitable, firms have therefore become more aggressive in developing the appropriate competitive strategies (Nyambane and Bett, 2018), and are paying a lot of attention to the quality of products, costs of production, and supply chains (International Trade Centre, 2019).

Competitive strategies are explained by Rono (2015) as the approaches that a firm takes to gain a desired market position and hence achieve a competitive advantage over its competitors. This is in agreement with Porter (1980) whose theory explains that the aim of competitive strategies is to give an enterprise profits which are above average. Safaricom (2019) equally posit that firms that adopt carefully selected competitive strategies usually have competitive advantage and hence improved performance. A business that adopts strategies that are difficult to replicate achieves competitive advantage and has higher chances of being more profitable than competitors (Abubakar and Mohammad, 2019). Consequently, a number of strategy profiles such as those of Parnell (2002), Hooley and Greenley (2005), Spanos and Lioukas (2001), Hayes and Schmenner (1978), White (2004), Miles and Snow (1978), and Porter (1980) among others have been advanced and emphirically tested (Atikiya, 2015; Mukhezakule and Tefera, 2019; KPMG, 2019).

The global dairy industry is characterized by large, medium and small scale enterprises, and plays a major role in the economies of the different nations (Herr and Nettekokoven, 2017). Currently, there is an increasing demand for dairy products due to factors such as consumption spending my middle class consumers, rising populations, urbanization, and changing diets in favour of processed dairy products (Vitaliano, 2016). According to Food and Agriculture Organization Statistics (FAOSTAT, 2016) this global demand is expected to increase by $2.5 \%$ per annum by 2020 .

However, the global performance of the dairy industry has been declining (United States Department of Agriculture, 2019) due to factors such as reduction of market share, reduced profits, loss of customer satisfaction, stiff competition, and lack of appropriate management strategies (Mighty, 2016).

Africa's dairy sector has in the past been largely owned by the respective governments, with little private sector involvement (Ministry of Agriculture, Livestock, Fisheries and Irrigation, 2019). Since the liberalization of economies in the continent, there has been extensive expansion of small and medium dairy enterprises and their related infrastructure (USDA, 2019). Demand for dairy products in the continent is also increasing due to population and economic growth, increased urbanization, and adoption of Western eating habits (Ministry of Agriculture, Livestock, Fisheries and Irrigation, 2019). As peoples' incomes in Africa increase, their demand for greater food variety, higher value products, and better quality processed dairy products also increases (European Commission, 2019).

Kenya's dairy industry, in comparison with other nations, is one of the largest in Sub-Saharan Africa (Bonilla et al., 2018). 
The industry is important in the economy of Kenya as it accounts for $14 \%$ of the nation's agricultural Gross Domestic Product (GDP), and between $6-8 \%$ of the country's GDP (Food and Agriculture Organization, FAO, 2019; Feed The Future, 2018). Studies show that the sector provides food to the population (Chege and Oloko, 2017). Further, the sector is a major source of employment and income to a large majority of Kenyans (Kamande, 2015), and provides a ready market for the raw milk produced by dairy farmers. One key strategy of the Government of Kenya is export since the country has the largest milk production in the continent after South Africa (Feed the Future, 2018).

Since Kenya's dairy sector was liberalized in 1992, the number of dairy processing firms has increased tremendously (Ministry of Agriculture, Livestock, Fisheries and Irrigation, 2019). A lack of appropriate strategies to manage most firms led to shortcomings which created openings for small and medium processors and a large informal sector which deals in raw milk (Bonilla et al., 2018). Bonilla et al. (2018) add that this situation has led to stiff competition in the industry, and constraints that inhibit growth such as low prices for raw milk, post-harvest milk losses, and lack of competitiveness. Consequently, some firms like Ilara Dairy, Spin Knit Dairy, Buzeki Dairy Ltd., and Delamere Dairies have been bought off by Brookside Dairies (Abiero and Njeru, 2016).

The sector is characterized by a small number of large dairy enterprises and many small and medium dairy firms (Feed the Future, 2018). The Kenya Dairy Board (KDB), which governs the industry, is mandated to work for the improvement and control of the products of the sector (Kiema, 2015). The industry consists of 29 milk processors, 67 Mini dairies, and a large informal sector (Kibogy, 2018). The industry is dominated by five large scale dairies: Brookside Dairies, New Kenya Cooperative Creameries (NKCC), Githunguri Dairies, Kinangop Dairies, and Meru Dairies, all of which process up to or more than 100,000 litres of milk per day (USAIDKAVES, 2015; Feed the Future, 2018).

Kenya's Small and Medium dairy sector consists of private processors which collectively control $31 \%$ of the market (Feed the Future, 2018). This sector serves a particular market segment as a way of avoiding direct competition with the large and well established dairy firms (Feed the Future, 2018). The sector is consequently associated with niche, high value, and unique products that target the high income earners (Feed the Future, 2018). To avoid being crowded out by the larger dairy firms, the small and medium dairy firms have opted to process products that respond to the changing demand patterns of the expanding middle income population of the country (Feed The Future, 2018).

The small and medium dairy processors in Nairobi County formed the scope of the study, and only dairy firms which were registered with the Kenya Dairy Board were considered. The reason for focusing the study on small and medium dairy processors was due to the fact that previous Cross sectional case studies Chege and Bula, 2015; Chege and Oloko, 2017;
Somba, 2016) focused only on large scale processors, meaning that little is known about small and medium scale dairy processors. Additionally, more than $80 \%$ of the small and medium dairy processors are concentrated in Nairobi County (Kenya Dairy Board, 2018), so the county was chosen as the area of study.

\section{METHODS}

The current study used descriptive cross-sectional survey research design. This design was considered appropriate to this study since it has the capacity for wide application and broad coverage (Yin, 2017). Using this design allowed the collection of data which defines and describes the characteristics of the 18 small and medium dairy processors in Nairobi County. This mitigated the disadvantages of other methods such as case studies where generalizability is limited (Yin, 2017).

The study used the quantitative approach of data analysis which quantifies data and allows the use of statistics to analyze it (Kapur, 2018). The quantitative approach was considered suitable to the current study because it is the most popular research approach in the examination of the relationship between different variables, the measurement of objective theories (Akhtar, 2016), and allows for the analysis of data using standard statistical tools (Yin, 2017).

The study was carried out in Nairobi County. The particular area was chosen because more than $80 \%$ of the small and medium dairy processors are concentrated in Nairobi (KDB, 2019), so the findings can be generalized to the remaining $20 \%$ located outside Nairobi.

The target population comprised all the small and medium dairy processors in Nairobi County. These processors are 19 in number (KDB, 2019), but one firm was used for pilot study leaving 18 firms for the study and reporting. Five questionnaires were distributed to each of the 18 dairy processors.

Small and medium dairy processors were chosen for this study because available previous studies mainly focused on New KCC and Kinangop Dairy Ltd, which are large dairy processors. The selection of the enterprises for this study was also based on the fact that small and medium dairy processors are key drivers of Kenya's economy towards Vision 2030, the Government of Kenya Big Four Development Agendas, and SDG 2 on achieving food security and improved nutrition. This is coupled by the fact that the small and medium dairy processors are threatened by the competition pressure created by their large scale counterparts.

The study aimed to find out the competitive strategies adopted by small and medium dairy processors in Nairobi County. The questionnaire was found to be the most appropriate instrument of data collection. The choice of the questionnaire tool is strengthened by the assertion of Kapur (2018) that the instrument measures existing relationships, and self-reported beliefs and behavior. Additionally, the questionnaire allows 
for quick and efficient collection of data and makes it possible for descriptive statistical analysis of data (Akhtar, 2016).

The choice of the questionnaire as a data collection tool is also founded on the fact that it is suitable for collecting a large amount of data from a large number of respondents within a short period of time. Additionally, the use of the questionnaire allows for confidentiality, and the results of the tool can easily be quantified and analyzed 'scientifically' and objectively.

The development of the questionnaire was based on previous studies. The constructs were adopted and modified from the study of Atikiya (2015). As Atikiya (2015) asserts, the use of a questionnaire which has been modified from previous studies contributes to the reliability and validity of the research instrument.

A Likert scale was designed for most of the constructs in the study. The choices in the scale were phrased as: to a very large extent, to a large extent, to a moderate extent, to a low extent, not at all. The scale provides ease in responding to questions, and enables ease in statistical analysis of data by the researcher.

Validity is the degree to which a construct measures what it is supposed to (Booth et al., 2016). To test the validity of the questionnaire at the point of designing it, it was adopted and modified from a previous study by Atikiya (2015), and consultations made with the college supervisors to ensure clarity and suitability of wording. Further, a pre-test was carried out on five managers from one processor chosen at random.

Reliability establishes whether scores are stable over time when the instrument is administered a second time (Kapur, 2018). The reliability of the research variables was computed using Cronbach Alpha method which measures the internal consistency by establishing if certain items within a scale measure the same construct. The established Alpha value threshold is at 0.7 , thus forming the study's benchmark (Yin, 2017). A reliability value of the scales exceeding the prescribed threshold of 0.7 implies that the research instrument is reliable (Booth et al., 2016). Cronbach Alpha was established for the different sections of the research instrument.

\section{RESULTS}

\section{Competitive Strategies adopted by the Dairy Processors}

On a five-point Likert scale, the study attempted to assess the extent to which the firms had implemented the various competitive strategies of Cost Leadership, Differentiation, Cost Focus, and Differentiation Focus. The scale ranged from Not at all (1) on the lower level to Low Extent (2), Moderate Extent (3), Large Extent (4), and Very Large Extent (5) on the higher level. This was a response to the research objectives of the current study, which sought to find out the competitive strategies the small and medium dairy processors had adopted.

\section{Indicators of Cost Leadership Strategy}

The respondents were asked to indicate, by use of a Likert scale of 1 - not at all, 2 - to a low extent, 3 - to a moderate extent, 4 - to a large extent, 5 - to a very large extent, the extent to which the various statements relating to Cost Leadership Strategy applied to their firm. Table 1 shows the frequency, percentage and mean of the responses as they range from the minimum (not at all) to the maximum (very large extent).

Table 1: Indicators of Cost Leadership Strategy

\begin{tabular}{|c|c|c|c|c|c|c|}
\hline Strategy & $\begin{array}{l}\text { Not at } \\
\text { all } \\
1\end{array}$ & $\begin{array}{l}\text { Low } \\
\text { Extent } \\
2\end{array}$ & $\begin{array}{l}\text { Moderat } \\
\text { e } \\
\text { Extent } \\
3\end{array}$ & $\begin{array}{c}\text { Large } \\
\text { Extent } \\
4\end{array}$ & $\begin{array}{c}\text { Very } \\
\text { Large } \\
\text { Extent } \\
5\end{array}$ & Mean \\
\hline $\begin{array}{l}\text { Cost cutting } \\
\text { and effective } \\
\text { utilization of } \\
\text { resources }\end{array}$ & - & - & $\begin{array}{c}10 \\
(12 \%)\end{array}$ & $\begin{array}{c}18 \\
(21.7 \% \\
)\end{array}$ & $\begin{array}{c}54 \\
(65.1 \% \\
)\end{array}$ & 4.54 \\
\hline $\begin{array}{l}\text { Firm has } \\
\text { access to low } \\
\text { cost raw } \\
\text { materials }\end{array}$ & $\begin{array}{c}3 \\
(3.6 \%)\end{array}$ & $\begin{array}{c}24 \\
(28.9 \\
\%)\end{array}$ & $\begin{array}{c}32 \\
(38.6 \%)\end{array}$ & $\begin{array}{c}20 \\
(24.1 \% \\
)\end{array}$ & $\begin{array}{c}1 \\
(1.2 \%)\end{array}$ & 2.90 \\
\hline $\begin{array}{c}\text { Firm serves } \\
\text { many industry } \\
\text { segments }\end{array}$ & $\begin{array}{c}3 \\
(3.6 \%)\end{array}$ & $\begin{array}{c}28 \\
(33.7 \\
\%) \\
\end{array}$ & $\begin{array}{c}33 \\
(39.8 \%)\end{array}$ & $\begin{array}{c}10 \\
(12 \%)\end{array}$ & $\begin{array}{c}10 \\
(12 \%)\end{array}$ & 3.02 \\
\hline $\begin{array}{c}\text { Firm sells } \\
\text { standardized } \\
\text { products }\end{array}$ & $\begin{array}{c}2 \\
(2.4 \%)\end{array}$ & - & $\begin{array}{c}13 \\
(15.7 \%)\end{array}$ & $\begin{array}{c}14 \\
(16.9 \% \\
)\end{array}$ & $\begin{array}{c}51 \\
(61.4 \% \\
)\end{array}$ & 4.43 \\
\hline $\begin{array}{l}\text { Firm takes } \\
\text { advantage of } \\
\text { unskilled } \\
\text { labor } \\
\text { surpluses }\end{array}$ & $\begin{array}{c}19 \\
(22.9 \% \\
)\end{array}$ & - & $\begin{array}{c}9 \\
(10.8 \%)\end{array}$ & $\begin{array}{c}41 \\
(49.4 \% \\
)\end{array}$ & $\begin{array}{c}13 \\
(15.7 \% \\
)\end{array}$ & 3.35 \\
\hline $\begin{array}{c}\text { Firm charges } \\
\text { lower prices } \\
\text { than its } \\
\text { competitors }\end{array}$ & $\begin{array}{c}8 \\
(9.6)\end{array}$ & $\begin{array}{c}13 \\
(15.7 \\
\%)\end{array}$ & $\begin{array}{c}39 \\
(47 \%)\end{array}$ & $\begin{array}{c}12 \\
(14.5 \% \\
)\end{array}$ & $\begin{array}{c}10 \\
(12 \%)\end{array}$ & 3.04 \\
\hline $\begin{array}{l}\text { Firm heavily } \\
\text { invests in } \\
\text { sales } \\
\text { promotion } \\
\end{array}$ & $\begin{array}{c}11 \\
(13.3 \% \\
)\end{array}$ & $\begin{array}{c}9 \\
(10.8 \\
\%)\end{array}$ & $\begin{array}{c}52 \\
(62.7 \%)\end{array}$ & $\begin{array}{c}5 \\
(6 \%)\end{array}$ & $\begin{array}{c}2 \\
(2.4 \%)\end{array}$ & 3.28 \\
\hline $\begin{array}{l}\text { Firm retains } \\
\text { employees by } \\
\text { offering them } \\
\text { benefits }\end{array}$ & $\begin{array}{c}11 \\
(12.3 \% \\
)\end{array}$ & $\begin{array}{c}23 \\
(27.7 \\
\%)\end{array}$ & $\begin{array}{c}25 \\
(36.1 \%)\end{array}$ & $\begin{array}{c}11 \\
(13.3 \% \\
)\end{array}$ & $\begin{array}{c}9 \\
(10.8 \% \\
)\end{array}$ & 3.73 \\
\hline $\begin{array}{c}\text { Firm gives its } \\
\text { customers } \\
\text { Discounts }\end{array}$ & $\begin{array}{c}13 \\
(15.7 \% \\
)\end{array}$ & $\begin{array}{c}27 \\
(32.5 \\
\%) \\
\end{array}$ & $\begin{array}{c}36 \\
(43.4 \%)\end{array}$ & $\begin{array}{c}6 \\
(7.2 \%)\end{array}$ & - & 3.57 \\
\hline $\begin{array}{c}\text { Firm reduces } \\
\text { labour costs } \\
\text { by use of } \\
\text { automation }\end{array}$ & $\begin{array}{c}16 \\
(19.3 \% \\
)\end{array}$ & $\begin{array}{c}24 \\
(28.6 \\
\%)\end{array}$ & $\begin{array}{c}26 \\
(31.3 \%)\end{array}$ & - & $\begin{array}{c}17 \\
(20.5 \% \\
)\end{array}$ & 3.47 \\
\hline $\begin{array}{l}\text { Firm sources } \\
\text { from suppliers } \\
\text { who give } \\
\text { discounts }\end{array}$ & $\begin{array}{c}18 \\
(21.7 \% \\
)\end{array}$ & $\begin{array}{c}12 \\
(14.5 \\
\%)\end{array}$ & $\begin{array}{c}36 \\
(43.4 \%)\end{array}$ & - & $\begin{array}{c}17 \\
(20.5 \% \\
)\end{array}$ & 3.37 \\
\hline $\begin{array}{c}\text { Firm } \\
\text { outsources } \\
\text { functions to } \\
\text { control costs }\end{array}$ & $\begin{array}{c}22 \\
(26.5 \% \\
)\end{array}$ & $\begin{array}{c}6 \\
(7.2 \%)\end{array}$ & $\begin{array}{c}35 \\
(42.2 \%)\end{array}$ & $\begin{array}{c}12 \\
(14.5 \% \\
)\end{array}$ & $\begin{array}{c}7 \\
(8.4 \%)\end{array}$ & 3.29 \\
\hline $\begin{array}{c}\text { Firm } \\
\text { identifies } \\
\text { under- } \\
\text { performing } \\
\text { areas and }\end{array}$ & $\begin{array}{c}31 \\
(37.3 \% \\
)\end{array}$ & $\begin{array}{c}16 \\
(19.3 \\
\%)\end{array}$ & $\begin{array}{c}23 \\
(27.7 \%)\end{array}$ & $\begin{array}{c}12 \\
(14.5 \% \\
)\end{array}$ & $\begin{array}{c}1 \\
(1.2 \%)\end{array}$ & 3.77 \\
\hline
\end{tabular}




\begin{tabular}{|c|c|c|c|c|c|c|}
\hline $\begin{array}{c}\text { takes } \\
\text { corrective } \\
\text { measures }\end{array}$ & & & & & & \\
\hline $\begin{array}{c}\text { JIT purchases } \\
\text { of raw } \\
\text { materials }\end{array}$ & $\begin{array}{c}17 \\
(20.5 \% \\
)\end{array}$ & $\begin{array}{c}8 \\
(9.6 \%)\end{array}$ & $\begin{array}{c}30 \\
(36.1 \%)\end{array}$ & $\begin{array}{c}18 \\
(21.7 \% \\
)\end{array}$ & $\begin{array}{c}9 \\
(10.8 \% \\
)\end{array}$ & 3.07 \\
\hline $\begin{array}{c}\text { Firm strives to } \\
\text { reduce } \\
\text { administration } \\
\text { costs }\end{array}$ & $\begin{array}{c}20 \\
(24.1 \% \\
\text { co }\end{array}$ & $\begin{array}{c}9 \\
(10.8 \\
\%)\end{array}$ & $\begin{array}{c}31 \\
(37.3 \%)\end{array}$ & $\begin{array}{c}19 \\
(22.9 \%\end{array}$ & $\begin{array}{c}2 \\
(2.4 \%)\end{array}$ & 3.32 \\
\hline
\end{tabular}

Majority of the respondents, 54 (65.1\%), agreed that the firms used cost cutting and efficient use of resources to a very large extent. A main feature of cost leadership which reduces production costs is the production and sale of standardized goods, which was agreed to by $51(61.4 \%)$ of the respondents to a very large extent.

Cost leaders use sales promotion to reach a wide market. In relation to this, $52(62.7 \%)$ respondents were of the opinion that they invested heavily in sales promotion. Firms that take advantage of unskilled labour surpluses benefit from reduced labour costs. The study revealed that 41 (49.4\%) of the respondents had adopted the cost leadership strategy to a large extent.

A feature that may add to costs and disadvantage the firm that seeks cost leadership is failure to identify under-performing areas and carry out corrective measures. Noticeably, 31 $(37.3 \%)$ of the respondents with a mean of 3.77 indicated that their firms failed in this aspect.

From the study, cost cutting and efficient use of resources, and sale of standardized products had the highest mean of 4.54 and 4.43 respectively, implying that most of the firms sought cost leadership through the two strategies. The average mean of the responses relating to Cost Leadership Strategy was 3.45. This implies that the opinion of most of the respondents was that their firms had adopted the Cost Leadership Strategy to a moderate extent.

\section{Indicators of Differentiation Strategy}

The respondents were required to state how their firm created a unique image of itself. Uniqueness in an industry is a central characteristic of firms seeking differentiation, and can be achieved in different ways as shown in figure 1 .

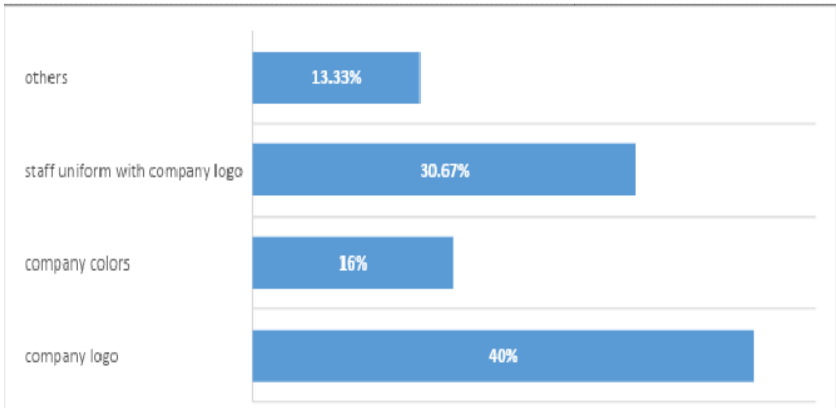

Figure 1: Unique Image
As evidenced in figure 1, forty percent (40\%) of the respondents were of the opinion that company logo was used to create a unique image of the firms. Firms which used staff uniform with company logo to create a unique image had a percentage of 30.67 respondents, while $16 \%$ used company colours. A minority of respondents, $13.33 \%$, reported that some businesses used the brand to create uniqueness in firm image. This study established that the firms in the latter category had very strong and unique brands in the market.

Further, the respondents were asked to indicate on a Likert scale of not at all (1), to a low extent (2), to a moderate extent (3), to a large extent (4), and to a very large extent (5), the extent to which firms had adopted the listed statements that apply to Differentiation Strategy. Table 2 summarizes the findings in frequencies, percentages, and mean.

Table 2: Indicators of Differentiation Strategy

\begin{tabular}{|c|c|c|c|c|c|}
\hline $\begin{array}{c}\text { Attributes of } \\
\text { Differentiation } \\
\text { Strategy }\end{array}$ & $\begin{array}{l}\text { Low } \\
\text { Extent } \\
2\end{array}$ & $\begin{array}{c}\text { Modera } \\
\text { te } \\
\text { Extent } \\
3 \\
\end{array}$ & $\begin{array}{l}\text { Large } \\
\text { Extent } \\
\quad 4\end{array}$ & $\begin{array}{l}\text { Very } \\
\text { Large } \\
\text { Extent } \\
5 \\
\end{array}$ & $\begin{array}{c}\text { Mea } \\
n\end{array}$ \\
\hline $\begin{array}{c}\text { Superior Designs } \\
\text { and Customer } \\
\text { Service }\end{array}$ & & $\begin{array}{c}11 \\
(13.3 \%)\end{array}$ & $\begin{array}{c}18 \\
(21.7 \%)\end{array}$ & $\begin{array}{c}54 \\
(65.1 \%)\end{array}$ & 4.52 \\
\hline $\begin{array}{c}\text { Production of } \\
\text { Superior products }\end{array}$ & & $\begin{array}{c}11 \\
(13.3 \%)\end{array}$ & $\begin{array}{c}19 \\
(22.9 \%)\end{array}$ & $\begin{array}{c}53 \\
(63.9 \%)\end{array}$ & 4.51 \\
\hline $\begin{array}{l}\text { Heavy investment } \\
\text { in Research \& } \\
\text { Development }\end{array}$ & $\begin{array}{c}13 \\
(15.7 \%)\end{array}$ & $\begin{array}{c}12 \\
(14.5 \%)\end{array}$ & $\begin{array}{c}11 \\
(13.3 \%)\end{array}$ & $\begin{array}{c}46 \\
(55.4 \%)\end{array}$ & 4.1 \\
\hline $\begin{array}{l}\text { Safeguards patents } \\
\text { and intellectual } \\
\text { property }\end{array}$ & & $\begin{array}{c}16 \\
(19.3 \%)\end{array}$ & $\begin{array}{c}12 \\
(14.5 \%)\end{array}$ & $\begin{array}{c}55 \\
(66.3 \%)\end{array}$ & 4.47 \\
\hline $\begin{array}{l}\text { Offers high quality } \\
\text { services and } \\
\text { products }\end{array}$ & & & $\begin{array}{c}22 \\
(26.5 \%)\end{array}$ & $\begin{array}{c}61 \\
(73.5 \%)\end{array}$ & 4.73 \\
\hline $\begin{array}{l}\text { Unique, talented, } \\
\text { experienced } \\
\text { personnel }\end{array}$ & $\begin{array}{c}1 \\
(1.2 \%)\end{array}$ & $\begin{array}{c}9 \\
(10.8 \%)\end{array}$ & $\begin{array}{c}13 \\
(15.7 \%)\end{array}$ & $\begin{array}{c}60 \\
(72.3 \%)\end{array}$ & 4.59 \\
\hline $\begin{array}{l}\text { Firm purchases } \\
\text { quality inputs }\end{array}$ & & & $\begin{array}{c}16 \\
(19.3 \%)\end{array}$ & $\begin{array}{c}67 \\
(80.7 \%)\end{array}$ & 4.81 \\
\hline $\begin{array}{l}\text { Rigorous quality } \\
\text { control to become } \\
\text { quality leader }\end{array}$ & & $\begin{array}{c}1 \\
(1.2 \%)\end{array}$ & $\begin{array}{c}24 \\
(28.9 \%)\end{array}$ & $\begin{array}{c}58 \\
(69.9 \%)\end{array}$ & 4.69 \\
\hline $\begin{array}{c}\text { Constant new } \\
\text { product } \\
\text { development/impro } \\
\text { vement }\end{array}$ & & $\begin{array}{c}12 \\
(14.5 \%)\end{array}$ & $\begin{array}{c}24 \\
(28.9 \%)\end{array}$ & $\begin{array}{c}47 \\
(56.6 \%)\end{array}$ & 4.42 \\
\hline $\begin{array}{l}\text { Great importance } \\
\text { laid on product } \\
\text { features (design) }\end{array}$ & & $\begin{array}{c}20 \\
(24.1 \%)\end{array}$ & $\begin{array}{c}15 \\
(18.1 \%)\end{array}$ & $\begin{array}{c}47 \\
(56.6 \%)\end{array}$ & 4.33 \\
\hline $\begin{array}{l}\text { Maintains and } \\
\text { protects brand } \\
\text { image }\end{array}$ & $\begin{array}{c}1 \\
(1.2 \%)\end{array}$ & $\begin{array}{c}10 \\
(12 \%)\end{array}$ & $\begin{array}{c}18 \\
(21.7 \%)\end{array}$ & $\begin{array}{c}53 \\
(63.9 \%)\end{array}$ & 4.5 \\
\hline $\begin{array}{l}\text { Firm consciously } \\
\text { makes products } \\
\text { different from those }\end{array}$ & $\begin{array}{c}2 \\
(2.4 \%)\end{array}$ & $\begin{array}{c}16 \\
(14.3 \%)\end{array}$ & $\begin{array}{c}21 \\
(25.4 \%)\end{array}$ & $\begin{array}{c}43 \\
(51.8 \%)\end{array}$ & 4.28 \\
\hline
\end{tabular}




\begin{tabular}{|c|c|c|c|c|c|}
\hline of competitors & & $\begin{array}{c}14 \\
(16.9 \%)\end{array}$ & $\begin{array}{c}27 \\
(32.5 \%)\end{array}$ & $\begin{array}{c}41 \\
(49.4 \%)\end{array}$ & 4.33 \\
\hline $\begin{array}{c}\text { More innovative } \\
\text { products than those } \\
\text { of competitors }\end{array}$ & 1 & $\begin{array}{c}21 \\
(25.3 \%)\end{array}$ & $\begin{array}{c}11 \\
(13.3 \%)\end{array}$ & $\begin{array}{c}49 \\
(59.4 \%)\end{array}$ & 4.32 \\
\hline $\begin{array}{c}\text { Products have } \\
\text { strong brand } \\
\text { identification }\end{array}$ & $(1.2 \%)$ & $\begin{array}{c}7 \\
7\end{array}$ & $\begin{array}{c}21 \\
(25.3 \%)\end{array}$ & $\begin{array}{c}54 \\
(65.1 \%)\end{array}$ & 4.57 \\
\hline $\begin{array}{c}\text { Strives to build } \\
\text { strong reputation in } \\
\text { the industry }\end{array}$ & & $(8.4 \%)$ & \\
\hline
\end{tabular}

According to Table 2, all the firms had adopted the differentiation strategies to a very large extent. For most of the firms, the quality of the purchased inputs was of prime importance as evidenced by $67(80.7 \%)$ respondents with a mean of 4.81. High quality inputs produce high quality outputs which are a key differentiation factor. Sixty-one respondents $(73.5 \%)$ reported that they offered high quality services and products to their customers, which is possible with committed staff; so $60(72.3 \%)$ respondents ascertained that the firms had unique, talented and experienced personnel.

Fifty-eight respondents, with a mean of 4.69, confirmed that rigorous quality control with the aim of becoming a quality leader in the market was being carried out. That the firms strove to build a strong reputation within the industry was indicated by 54 (65.1\%), while a similar number of respondents indicated that the firms stressed superior product design and superior customer service.
Emphasis on the production of superior products was of importance to firms as indicated by $53(63.9 \%)$ respondents, while a similar number with a mean of 4.51 reported that the firms made efforts to maintain and protect their brand image a factor which is essential for remaining ahead of competitors. Forty-nine (59.4\%) of the respondents ascertained that their firms had products with a strong brand identification, while 47 (56.6\%) confirmed that the firms constantly carried out new product development and improvement to meet the changing tastes and preferences of customers. A similar number of 47 $(56.6 \%)$ also indicated that great importance was laid on product features like functionality, durability, colour, size, shape, taste, and packaging.

The firms that heavily invested in research and development had a mean of 4.1 , while $43(51.8 \%)$ made conscious efforts to make their products different from those of competitors, as $41(49.4 \%)$ strove to introduce more innovative products than competitors. The average mean of the Differentiation Strategy was 4.45 , implying that from a Likert scale of 1-5 the most agreed to opinion was that the firms used the strategy to a large extent.

\section{Indicators of Cost Focus Strategy}

The participants in the study were required to give their opinion on Cost Focus Strategy. Figure 2 shows the percentages of their responses concerning the given statements which relate to Cost Focus Strategy.

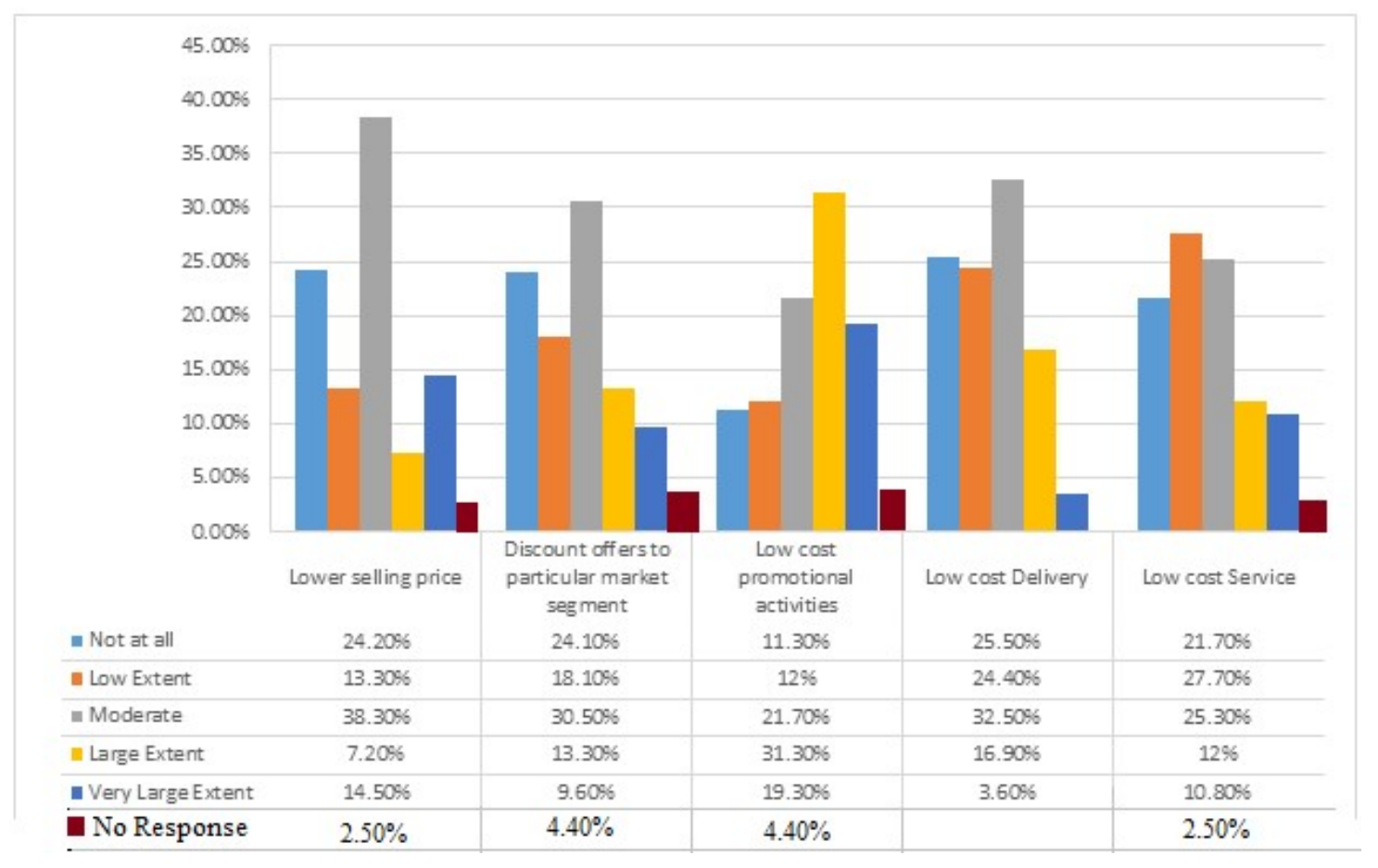

Figure 2: Indicators of Cost Focus Strategy 
On the aspect of the selling price, $38.30 \%$ of the respondents indicated that they offered lower selling prices for a particular market segment to a moderate extent, while $24.2 \%$ did not lower selling prices to particular market segment at all.

Concerning discount offers, $30.5 \%$ of the respondents indicated that they offered discounts to a particular market segment to a moderate extent, as $24.10 \%$ indicated that no discounts were given to particular markets at all. Findings from the study on promotional activities indicated that $31.3 \%$ of the firms had adopted low cost promotional activities that targeted a particular market segment to a moderate extent, while a similar number adopted the strategy to large extent. Some firms did not use the strategy at all as depicted by $11.3 \%$.

The respondents were also required to state the extent to which their firms arranged for low cost delivery of products to a particular market segment. Out of the 83 respondents, $32.5 \%$ confirmed that their firms targeted a particular market segment with a lowered delivery cost to a medium extent, and $24.4 \% \%$ to a low extent. Conversely, a percentage of 25.5 of the firms did not adopt the strategy at all. In response to efficiency in services, $27.70 \%$ of the respondents confirmed that to a low extent, their firms offered efficient and low cost service to a narrow strategic market, while $25.30 \%$ offered the services to a moderate extent. Additionally, $21.7 \%$ of the respondents stated that their efficient and low cost services did not target a narrow and strategic market at all.

The average mean of the variables in figure 2 is $M=2.78$. This shows that the preferred opinion of the participants on the variables was not at all from the Likert scale of 1-5, implying that the firms in the study did not use the strategy much. Since Cost Focus as a strategy means producing at low costs and selling at low prices to a targeted market, it can result in additional costs when the firm is small in size as is the case with the dairy firms in the current study. This may explain why the firms seem not to have adopted the strategy much.

\section{Indicators of Differentiation Focus Strategy}

The participants of the study were asked to indicate on a Likert scale of not at all (1), to a low extent (2), to a moderate extent (3), to a large extent (4), and to a very large extent (5), the extent to which their firm had adopted Differentiation Focus strategy. Figure 3 shows the responses to the different types of measures of Differentiation Focus Strategy.

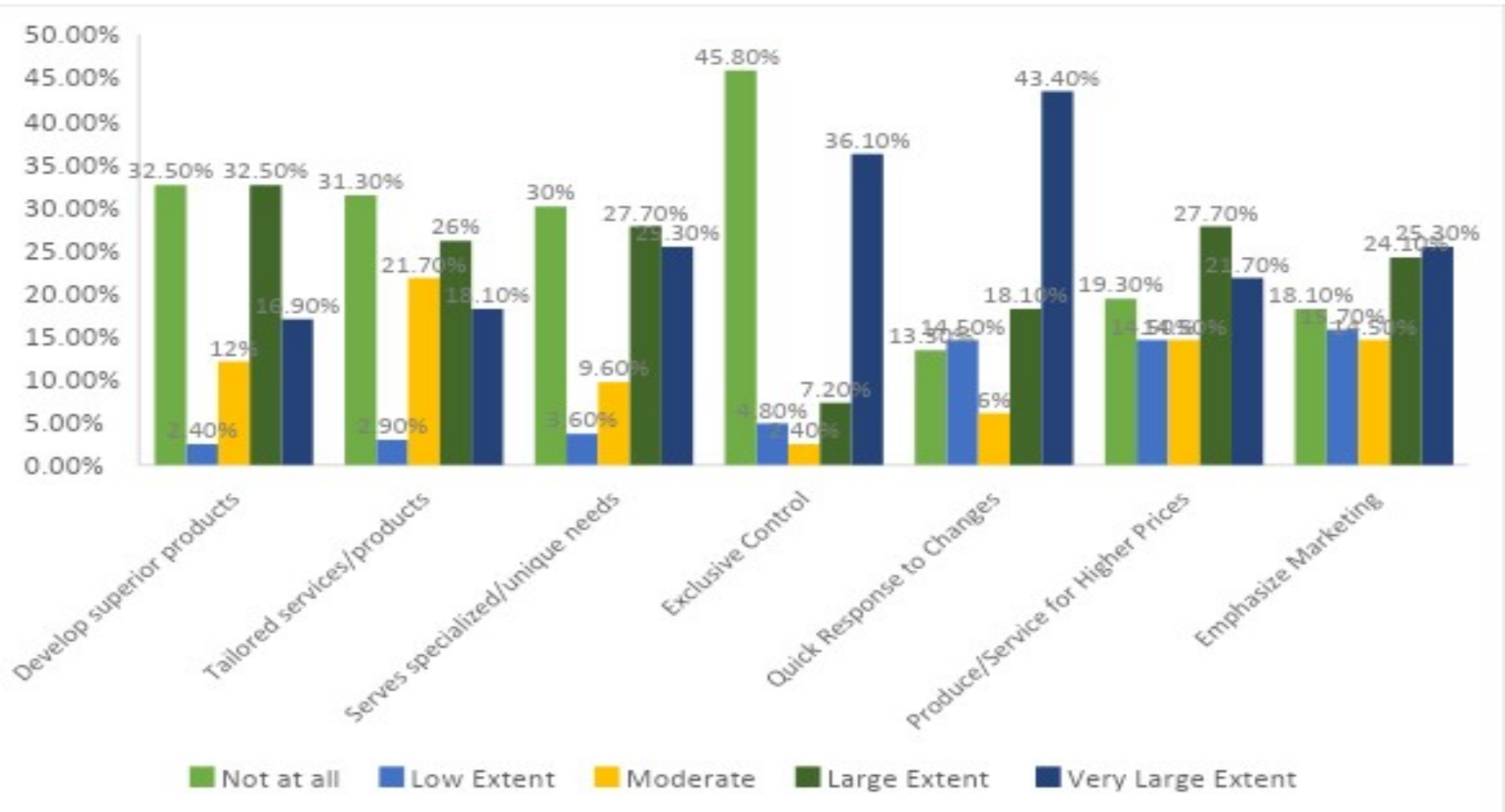

Figure 3: Indicators of Differentiation Focus Strategy

The firms that developed superior products for a niche market segment to a large extent were presented as $32.5 \%$ and $16.9 \%$ to a very large extent, totaling to $49.4 \%$. Noticeably from Figure 3, thirty two point five percent $(32.50 \%)$ did not adopt this strategy at all. Firms can focus their differentiation to a niche market through tailored products. In the current study, a total of $71.1 \%$ respondents indicated that firms had adopted this strategy, but $31.3 \%$ had not tailored their products for a niche market at all. Nevertheless, the findings show the majority of the dairy firms in the study as preferring to serve a niche market. 
The findings also indicate that majority of the firms did not have exclusive control over the production of the milk they processed, as represented by $45.8 \%$ of the respondents. Failure to control the milk input for processing could lead to production of poor quality output. However, 36.1\% exclusively controlled the milk input to a very large extent, and this could translate into better quality outputs.

On the type of needs that the firms served, $53 \%$ of the participants responded that the firms served the specialized and unique needs of their customers to a large extent. However, a large percentage of 30 did not use the strategy at all, possibly due to the fact that a small firm might incur added expenses in focusing on serving the specialized needs of a segment of customers.

Quick and timely response to the ever changing customer needs is an important aspect of focused differentiation. As can be deduced from Figure 4, 43.4\% of the respondents agreed that the firms gave a fast response to demand changes in their customers. This is an aspect that ensures customer satisfaction and may create loyalty to the firm. However, some respondents represented by $43.4 \%$ confirmed that the firms did not apply the particular strategy.

In response to the type of segment the firms served, a total of $49.4 \%$ of the respondents reported that goods were produced for higher price segments, indicating a certain level of focused differentiation. The average mean of the responses on Differentiation Focus Strategy was $\mathrm{M}=3.25$, which implies that the dairy firms had adopted the strategy to a moderate extent.

\section{Competitive Strategies adopted by the Dairy Firms}

In an effort to establish the extent to which the dairy firms in the study had adopted Porter's competitive strategies, the findings from the indicators of each strategy were summarized and presented in percentages. Figure 4 summarizes in percentages, the competitive strategies which the dairy firms had adopted.

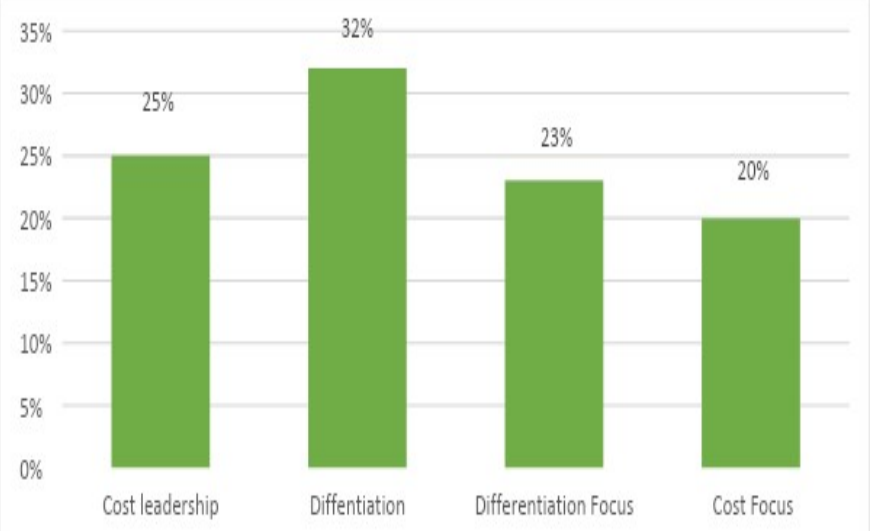

Figure 4: Summary of the Strategies adopted by the Firms in Percentages It is evidenced in figure 4 that Differentiation (32\%) was the most preferred strategy since it had the highest percentage, with an average mean of 4.45. From the Likert scale of 1 (not at all), 2 (to a low extent), 3 (to a moderate extent), 4 (to a large extent) 5 (to a very large extent), it can be deduced that the enterprises had implemented the differentiation strategy to a large extent. Cost Leadership Strategy with a mean of 3.45 had a $25 \%$ preference, while Differentiation Focus at $23 \%$ had a mean of 3.25. The firms had adopted both Differentiation Focus and Cost Leadership strategies to a moderate extent, while Cost Focus $(20 \%)$ with a mean of 2.78 was adopted to a low extent.

\section{DISCUSSION}

\section{Indicators of Cost Leadership Strategy}

In the current study, the dairy firms have adopted the aspects of cost cutting, efficient use of resources, and mass production of standardized goods to a very large extent. This is in agreement with findings by Njuguna and Waithaka (2020), whose study on cost leadership and organizational performance of insurance firms in Nyeri County established that the firms had implemented cost reduction strategies and production of standardized goods to a very large extent. Similarly, studies by Muia (2017) on the effect of Competitive Strategies on the Performance of Insurance Companies in Kenya indicated that the firms had adopted cost cutting and low prices strategies to a large extent. In the dairy industry in Kenya, Chege and Bula, 2015 attempted to establish the effect of generic strategies on the performance of New KCC in Kenya. The study found out that a lowered cost of production led to increased volume of sales.

According to Yuliansyah and Jermias (2018) and Tan (2017), these attributes of the cost leadership strategy enable a firm to produce goods at a low cost and to offer them to the market at a price that is lower than that of competitors. By minimizing and eliminating costs through the production of high volumes of low cost standardized goods which are offered to a large customer base (Lindstad et al. 2016), the firm appeals to the cost conscious and price sensitive customers, sells at a discount while still generating a profit (Salavou, 2015; Soltanizadeh, 2016), and hence becomes a cost leader.

\section{Indicators of Differentiation Strategy}

The dairy firms in the study continuously work at developing new differentiated products. A strong reputation of high quality products and services in the industry, quality control, and a strong brand image are important aspects of the differentiation competitive strategy which the dairy firms in the study had adopted. These findings concur with findings from the study of Atikiya (2015) which indicated that the manufacturing firms in the study implemented the aspects of superior products and services, protection of the companies' brand image and a strong brand identification. A study by Onyango (2017) on the competitiveness of British Oxygen 
Company also established that the firm had adopted the aspects of strong brand identification and strong reputation.

According to Subrahmanyam and Azad (2019), an enterprise can use differentiation as a strategy to achieve competitive advantage. In implementing this strategy, an organization identifies the specific attributes which are valued by buyers in the industry and then develops strategies on how to uniquely position itself to meet those needs (Dombrowski et al., 2018). A premium price for this uniqueness is charged by the firm. According to Pehrsson (2016), the key characteristic of the strategy is perceived quality. When the firm succeeds to differentiate itself in attributes that are different from its rivals - for instance in service, quality, style, design, or product features - it becomes the differentiated leader in those particular aspects (Karyani and Rossieta, 2018). The firms in the current study had differentiated themselves in unique quality, service, reputation, and brand.

\section{Indicators of Cost Focus Strategy}

The findings of the current study indicated that the dairy firms had focused on particular segments of the market and reduced the prices of the goods and services they offered to the segment, and delivered products to the particular segment at lowered costs. Discounts were offered to the selected segments, and to a very large extent carried out low cost promotional activities within the particular segment. This is in line with the work of Onyango (2017) which established that British Oxygen Company had lowered the cost of delivery, cost of services, and was offering discounts and lowered prices to selected market segments. Studies by Atikiya (2015) and Odunayo (2018) also concur with the findings of the current study - that the firms had reduced costs and selling prices for selected market segments.

When a firm adopts the Cost Focus strategy it chooses a narrow competitive scope within an industry (Muia, 2017), or selects a segment or group of segments in the industry and tailors its activities to serving them to the exclusion of others (Onyeaghala and Odiba, 2018). In cost focus a firm seeks a cost advantage in its target segment, and exploits differences in cost behavior in those segments (Atikiya, 2015).

\section{Indicators of Differentiation Focus}

A firm that adopts the differentiation focus strategy is known to seek differentiation in a target segment (Atikiya, 2015). It identifies the special needs of buyers in the particular target segment, and designs products exclusively for the satisfaction of the needs of the focused market segment (Muia, 2017). In the current study, the dairy firms were producing superior products for selected market segments, tailored their products to suit the needs and preferences of the segment, had exclusive control of firm inputs, and responded quickly to market changes to a large extent. This is in agreement with findings by Somba (2016), Bundi (2017), Chege and Oloko (2017) and Asena (2019).

\section{Strategies adopted by the Dairy Firms}

The dairy firms in the study had adopted more of the differentiation strategy than the cost leadership and focus strategies. The findings of this study concur with the findings of studies by Njuguna, (2015); and Atikiya, (2015), who in their studies on competitive strategies established that the firms had adopted the Differentiation strategy more than Cost Leadership, Cost Focus and Differentiation Focus strategies. On the contrary, Mutunga and Minja (2014) in their study on competitive strategies and the beverage industry confirmed that Cost Leadership was the most preferred strategy. Subrahmanyam and Azad (2019) in their study on Carrefour's Competitive Strategy also found out that the firm had adopted more of the attributes of the Cost Leadership strategy than differentiation strategy.

Other studies on the competitiveness of firms have indicated that some organizations tend to adopt a combination of strategies to achieve greater competitiveness. For instance, the study by Mutunga and Minja (2014) indicated that the majority of the firms in the beverage industry had embraced the Hybrid strategies (combination of Cost Leadership and Differentiation). Also, findings of studies by Bayraktar et al. (2017), Slijper (2017), on the competitiveness of firms showed that the firms in their study had adopted more of the hybrid strategies than the pure strategies.

This implies that the appropriateness of competitive strategies to a firm may depend on the particular industry and the size of the firm, so generalization across industries may not be valid. All strategies may not have the same effect in all industries. This is confirmed by Kerama and Simba (2019) whose study concluded that the differentiation strategy was more suited to e-business, while Njuguna (2015) established from his study that cost leadership as a strategy was not suited to multinationals.

In the present day's dairy industry which is characterized by stiff competition and domination from the four large dairy firms that control a larger market share compared to the $31 \%$ that small and medium dairy processors command, the differentiation strategy may be the solution for the latter's continued survival in the industry. Concentration on unique products and services can give the firms a competitive edge in the industry. Cost Leadership as a strategy may not be very appealing to small and medium firms because their size may not allow the absorption of costs to an extent that the firm can sell products at prices lower than competitors and still achieve the same level of profits.

The Focus strategy may suit smaller firms who do not have the resources to offer products in the wide market which is served by the large scale organizations. However, the small and medium dairy enterprises in the current study seem not to have adopted much of the Focus strategy. One challenge of the strategy is that the firms need to have a steady customer base in order to make sustainable profits from the narrow market segment. Secondly the strategy also requires a sizeable segment of customers in terms of numbers for it to generate 
sustainable profits. Generally, a firm will adopt the strategy that mostly suits its size, type of business, and industry.

\section{REFERENCE}

[1] Abiero, I. O., \& Njeru, A. (2016). Effect of Marketing Expansion Acquisition Motive on Financial Performance of Manufacturing Companies of Kenya - A case of Brookside Diaries Limited. International Journal of Science and Research, 5(2), 319 -7064. DOI:10.21275/v5i5.nov163862

[2] Abubakar, I., \& Mohammad, H. (2019). Linking Product Line Strategies to Competitive Advantage. SEISENSE Journal Management, 2(4), 166. DOI: 10.33215/sjom.v2i4.166

[3] Akhtar, I. (2016). Research Design, Research in Social Science: Interdisciplinary Perspectives. New Dheli: Jamia Millia Islamia. https://www.researchgate.net

[4] Asena, M. D. (2019). Porter's Competitive Strategies Influence on Performance of Mobile Telecommunication Companies in Kenya. International Journal of Scientific Research and Management, 7(2). DOI https://doi.org/10.18535/ijsrm/v7i2.em05

[5] Atikiya, A. (2015). Effect of Competitive Strategies on the performance of Manufacturing Firms in Kenya. Jomo Kenyatta University of Agriculture and Technology Doctoral Thesis. Corpus ID: 55679976

[6] Bayraktar, C. A., Hancerliogullari, G., Cetingue, B., \& Calisir, F. (2017). Competitive Strategies, Innovation and Firm Performance; an Emprical Study in a Developing Economy. Technology Analysis and Strategic Management, 29(1), 38 - 52. DOI:10.1080/09537325.2016.1194973

[7] Bonilla, J., MarCarthy, N., Mugatha, S., Rai, N., Coombes, A., \& Brubaker, J. (2018). Impact Evaluation of Smallholder Dairy Commercialization Programme in Kenya. New Delhi: 3ie International Initiative for Impact Evaluation Report, 73. https://doi.org/10.23846/tw4IE73

[8] Booth, W., Colomb, G., Williams, J., Bizup, W., \& Gerald, F. (2016). The Craft of Research. 4th Edition. Chicago: University of Chicago Press. https://press.uchicago.edu

[9] Bundi, V. K. (2017). Competitive Strategies and Performance of the Banking Industry in Kenya. Kenyatta University Thesis. http://ir-library.ku.ac.ke/handle/123456789/19097

[10] Chege, P. M., \& Bula, H. O. (2015). Effect of Generic Strategies of Performance of Dairy Industries in Kenya - A Case of Kenya Cooperative Creameries. International Journal of Education and Research, 3(12). www.ijern.com.

[11] Chege, P., \& Oloko, M. (2017). Influence of Generic Strategies on Performance of Large Dairy Firms in Kenya. European Journal of Business and Management, ISSN 2222 - 1905 Paper ISSN 2222 2839. Corpus ID: 212577214

[12] Dombrowski, U., Krenkel, P., \& Wulbrandt, J. (2018). Strategic Positioning of Production within the Generic Competitive

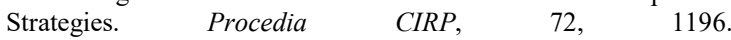
https://doi.org/10.1016/j.procir.2018.03.007

[13] European Commission. (2019). Urbanization as a driver of changing food demand in Africa - Evidence from Rural-Urban migration in Tanzania. Serville - Spain: Joint Research Centre. doi: $10.2760 / 515064$

[14] FAO. (2019). Kenya at a glance - The Agriculture sector in Kenya. Rome: FAO. http://hdl.handle.net/10419/172042

[15] FAOSTAT. (2016). The State of Food and Agriculture: Climate Change, Agriculture, and Food Security. Rome: FAOSTAT. http://www.fao.org

[16] Feed the Future. (2018). Policy Brief - Enhancing Investment Attractiveness in Kenya's Dairy Sector. The US Government's Global Hunger and Food Security Initiative. Nairobi: Climate Focus Kenya. https://www.usaid.gov

[17] Herr, H., \& Nettekokoven, Z. M. (2017). The Role of Small and Medium-sized Enterprises in Development. Abingdon: Routledge. http://hdl.handle.net/10419/189840

[18] International Trade Centre. (2019). Promoting SME Competitiveness in Kenya; Targeted Solutions for inclusive growth. Geneva: International Trade Centre. RSE-19-109.E
[19] Kamande, K. M. (2015). The Relationship between Financial Management Practices and Financial Performance in the dairy industry in Kenya. Doctoral Dissertation, University of Nairobi. http://hdl.handle.net/11295/94484

[20] Kapur, R. (2018). Research Methodology: Methods and Strategies. Dheli: University of Dheli. https://www.researchgate.net/publication/324588113

[21] Karyani, E., \& Rossieta, H. (2018). Generic Strategies and Financial Performance in the Banking Sector in Indonesia. Management and Accounting Review, 17(1). http://arionline.uitm.edu.my/ojs/index.php/MAR/article/view/672

[22] Kenya Dairy Board. (2018). The Milk Sector in Kenya. Nairobi: KDB. https://www.kdb.go.ke

[23] Kenya Dairy Board. (2019). Kenya Dairy Industry: Status and Outlook. The 15th ESADA Dairy Conference. Nairobi: Kenya Dairy Board. https://dairyafrica.com

[24] Kerama, R., \& Simba, F. (2019). Effect of Strategic Positioning on Firm Performance, A Survey on container Freight Station Operations in Mombasa County, Kenya. Strategic Journal of Business Change Management, 6(2), 201 - 226. https://strategicjournals.com

[25] Kibogy, M. (2018). Status and Outlook of the Dairy Industry in Kenya. 14th Africa Dairy Conference and Exhibition. Nairobi. https://dairyafrica.com

[26] Kiema, J. (2015). Influence of Information and Communication Technology on Choice of Competitive Strategies in Commercial Banks in Kenya. MBA Thesis - South Eastern Kenya University. http://repository.seku.ac.ke

[27] Kinyanjui, S., Oloko, M., Gachunga, H., \& Gathondu, B. (2016). Competition as a Response Srategy to Globalization by manufacturing firms in Kenya. International Journal of Business $\begin{array}{lll}\text { Administration, } & 6(5), & 6-48 .\end{array}$ https://doi.org/10.5430/ijba.v5n6p48

[28] KPMG International. (2019). Blending short and long term thinking in strategy. Amsterdam: Global Strategy Group. https://home.kpmg

[29] Laban, O. M., \& Deya, J. (2019). Strategic Innovations and the Performance of Information Communication Technology firms in Nairobi Kenya. International Journal of Academic Research in Progressive Education and Development, 8(12), 5599. DOI: 10.6007/IJARPED/v8-i2/5599

[30] Lindstad, H., Asbjornslett, B. E., \& Stromman, A. H. (2016). Opportunities for Increased Profit and Reduced Cost and Emission is by Differentiation within container. Shipping Maritime Policy and Management, 43(3), $280 \quad-294$. https://doi.org/10.1080/03088839.2015.1038327

[31] Mighty, M. (2016). The Jamaica Coffee Industry; Challenges and Responses to Increased Global Competition. In Globalization, Agriculture and Food in the Caribbean, 129 - 153. DOI:10.1057/978-1-137-53837-6 6

[32] Ministry of Agriculture, Livestock, Fisheries and Irrigation. (2019). Draft National Livestock Policy. Nairobi: Republic of Kenya. https://kilimo.go.ke

[33] Muia, F. (2017). Effect of Competitive Strategies on the Performance of Insurance Companies in Kenya. MBA Thesis United States International University Africa. http://www.iajournals.org/articles/iajhrba v3 i7 198 212.pdf

[34] Mukhezakule, M., \& Tefera, O. (2019). The Relationship between Corporate Strategy, Strategic Leadership and Sustainable Organizational Performance: Proposing a Conceptual Framework for the South African Aviation Industry. African Journal of Hospitality, Tourism and Leisure, 8(3), 12-15. ORCID: 00000001-5766-5335

[35] Mutunga, S. L., \& Minja, D. (2014). Generic strategies employed by food and beverage firms in Kenya and their effects on sustainable competitive advantage. International Journal of Business and Management Review. 2(6), 1-15. www.eajournals.org

[36] Njuguna, N. (2015). Effects of generic strategies on Competitive Advantage, Evidence from SMEEs in Nyahururu Kenya. SRN Electronic Journal, 10, 2139. DOI:10.2139/ssrn.2627795 
[37] Njuguna, S. N. \& Waithaka, P. (2020). Cost leadership strategy and organizational performance: A case of insurance companies in Nyeri County, Kenya. International Academic Journal of Human Resource and Business Administration, 3(9), 256-267. https://www.iajournals.org/articles/iajhrba v3 i9 256 267.pdf

[38] Nyambane, M. J., \& Bett, J. (2018). Competitive Advantage and Performance of heavy construction equipment suppliers in Kenya case of Nairobi County. International Academic Journal of Human Resource and Business Administration, 3(1), 476 - 502. http://ir-library.ku.ac.ke/handle/123456789/21021

[39] Odunayo, A. (2018). Market Focus Strategy and Organizational Performance of Telecommunication Companies in Port Harcout. International Journal of Innovative Research and Advanced Studies (IJIRAS), 5(3), 258. www.ijiras.com

[40] Omari, S., Matwere, R., \& Ogeto, C. (2016). The Competitive Strategies Adopted for Performance by private hospitals in Kisii County Kenya. African Journal of Business Management, 2. https://www.researchgate.net

[41] Onyango, J. J. (2017) Influence of Cost Leadership, Differentiation and Focus Strategies on Firm Competiveness: The Case of BOC Kenya Limited. MBA Thesis-United States

International University - $\quad$ Africa.
http://erepo.usiu.ac.ke/11732/3246

[42] Onyeaghala, O. H., \& Odiba, O. M. (2018). Generic Business Strategy as a Driver of Competitiveness in Organizations: A study of Selected Mobile Telecommunication Companies in Lagos, Nigeria. Journal of Business and Economic Development, 3(3), 86 - 96. http://creativecommons.org/licenses/by/4.0/

[43] Pehrsson, A. (2016). How does a foreign subsidiary's differentiation strategy fit competitive dynamics and mandate? European Business Review. DOI: 10.1108/EBR-08-2016-0107

[44] Porter, M. (1980). Competitive Strategy; Techniques for Analysing Industry and Competitors. New York: The Free Press. https://www.hbs.edu

[45] Rono, K. J. (2015). Effect of growth strategies on the competitiveness of firms in Kenyan Cement Industry; A case study of East Africa Portland Cement Company Limited. Strategic Journal of Business and Change Management, 2(2). http://www.strategicjournals.com/

[46] Safaricom. (2019). Towards reducing inequalities; 2019 Sustainable Business Report. Nairobi: Safaricom. Safaricomhttps://www.safaricom.co.ke >
[47] Salavou, H. E. (2015). Competitive Strategies and their shift to the future. European Business $\quad$ Review, 27(1), $80 \quad$ - 99. DOI:10.1108/EBR-04-2013-0073

[48] Schwab, K. (2019). The Global Competitiveness Report 2019. Geneva: World Economic Forum. www.weforum.org/gcr

[49] Slijper, T. (2017). The Impact of Strategies on the Financial Performance of European Investor-owned Dairy Processors. MsC Thesis. https://doi.org/10.13106/jafeb.2021.vol8.no7.0433

[50] Soltanizadeh, S. (2016). Business Strategy, Entrepreneur Risk Management and Organizational Performance. Management Research Review, $39 \quad$ (9), 6 - 15. http://www.emeraldinsight.com/10.1108/MRR-05-2015-0107?utm

[51] Somba, C. (2016). Marketing Strategies to be adopted by the Diary Industries to Improve Company Competitiveness: A case of Kinangop Dairy Ltd. MBA Thesis - Nairobi University. http://hdl.handle.net/11295/100198

[52] Subrahmanyam, S., \& Azad, F. A. (2019). Carrefour Competitive Strategy Cost Leadership and Differentiation. Thesis. https://www.researchgate.net

[53] Tan, K. (2017). Generic Internationalization Strategies of Emerging Market Multinationals; The Case of Chinese Firms. Advances in Economics and Business, 5(2), 83 - $84 . \quad$ DOI: 10.13189/aeb.2017.050205

[54] USAID-KAVES. (2015). Kenya Agricultural Value Chain Enterprises - Dairy Value Chain Analysis. NiairobI: Fintrac. https://pdf.usaid.gov

[55] USDA. (2019). 95th Annual Agricultural Outlook Forum, Growing Locally, Selling Globally. USDA, United States Department of Agriculture. Washington: USDA. https://www.usda.gov/media/press-releases/2018/10/25/usda

[56] Vitaliano, P. (2016). Global Dairy Trade; Where are we, How did we get here and Where are we going. International Food and Agribusiness Management Review, 19(B), 28 - 36. https://www.ifama.org

[57] Yin, R. (2017). Case Study Research and Applications: Design and Methods. Thousand Oaks: SAGE Publications. https://www.ebooks.com

[58] Yuliansyah, Y., \& Jermias, J. (2018). Strategic Performance Measurement System, Organizational Learning and Service Strategic Alignment Impact on Performance. International Journal of Ethics and Systems, 12(1), 8 - 17. DOI: 10.1108/IJOES-07-2018-0102 